\title{
Archives, Genealogies and Narratives in Women Workers' Education
}

\author{
Maria Tamboukou, Leverhulme Research Fellow, UEL
}

\section{Abstract}

In this contribution, I look back at my research of writing a genealogy of women workers' education and I map methodological moves and strategies that I have deployed in the process. While there is a rich body of literature around genealogical histories little has been written about a genealogical approach to archival work. It is precisely in the lacuna of how to do archival research from the situated position of a feminist genealogist that I look at three interrelated methodological and epistemological planes: a) living and re-imagining the archive; b) working with the possibilities and limitations of archival technologies of the self and c) considering the visual turn in the era of the digital revolution. While I perceive archival research as a process, I also take the archive as an event, marking discontinuities and ruptures in our modes of analysis and interpretation.

Key words: archive, digital revolution, events, feminist genealogies, process, visual turn

I never thought I would write about the history of women workers' education. The theme literally erupted from the archive and all I did was to follow its unexpected knock on my door. Michel Foucault has written about the visceral pleasures and astonishing surprises of the archive when recounting his experiences of reading letters from the Bastille prison collection: 'It would be hard to say exactly what I felt when I read these fragments. No doubt, one of these impressions that are called 'physical', as if there could be any other kind'. ${ }^{1}$ Foucault's intense 'physical' experiences of doing archival research, rare as they are in his writings, come as no surprise, given his long collaboration with the historian Arlette Farge, whose influential text, Le Gout de I'Archive, literally gives us a taste of the art of doing archival research. ${ }^{2}$

In this contribution, I look back at my recent research of writing a genealogy of women workers' education ${ }^{3}$ and I map methodological moves and strategies that I have deployed in the process. Women workers' education is a rather grey field in the history of women's education and yet it has played a crucial role in the intellectual lives of working women, whose contribution to the cultural formations of modernity has yet 
to be fully explored and evaluated. My discussion is framed within the wider project of writing feminist genealogies drawing on women's auto/biographical narratives. ${ }^{4}$ As a Nietzschean insight reconfigured in Michel Foucault's analytics, ${ }^{5}$ genealogy is concerned with the processes, procedures and apparatuses, whereby truth and knowledge are produced. Genealogy writes the history of the present: it problematizes the multiple, complex and non-linear configurations of the sociopolitical and cultural formations of modernity. In the context of my research: what were the conditions of possibility for women workers' education to emerge as a specific area of radical educational practices, why was it marginalized within the history of the labour movement and how has it become entangled in the constitution of a feminist consciousness, memory and culture?

Foucault's genealogical histories have opened up a rich and vibrant field of inquiries, but while a lot has been written about his genealogical approach as 'a history of the present $^{\prime}{ }^{6}$, the minutiae and micro-practices of his archival work have been mostly overpassed in the existing bodies of literature. It is precisely in the lacuna of how to do archival research from the situated position of a feminist genealogist that 1 particularly look at three interrelated methodological and epistemological planes: a) living and re-imagining the archive; b) working with the possibilities and limitations of what I have theorised as archival technologies of the self and c) considering the visual turn in the era of the digital revolution. In this context the archive is taken as a living organism, and thus a process in becoming, but it is also theorised in the light of the philosophies of 'the event'-an eruption that marks discontinuities and ruptures in our habitual modes of understanding and aligning with the real. ${ }^{7}$

This contribution follows methodological and epistemological trails we have already mapped in our co-authored book, The Archive Project. ${ }^{8}$ In this book's epilogue all 4 coauthors decided to write something about our future work in archival methodologies and in this context, I identified three areas that I wanted to expand: 'a) writing archival genealogies, that is, mapping discourses and practices that have created and shaped particular archival collections, as well as their subsequent readings, re-readings and rewritings; b) following up questions around archival troubles and failures; and c) creating digital meta-archives' ${ }^{9}$. It is therefore in the premises of these future directions that this contribution will be unfolding, particularly highlighting questions and problems around photographic archives, which is currently a bursting area of interest in the history of women's education and beyond.

\section{Living and re-imagining the archive}

I remember well the day that the history of women workers' education knocked on my door - its very date is inscribed in the word document's metadata: Thursday, July 7, 2011. It was late in the afternoon and I was tired after a whole day's work in the Manuscripts and Archives Division of the New York Public Library at the heart of a very hot summer. But in opening Box 1, there it was: the letter from the Bryn Mawr summer school for women workers written on August 4, 1922: 
My dearest comrade,

This will be the last letter you will receive from Bryn Mawr. Next week this time, I will be with you again in the dusty city doing my daily work in the shop and spending the evenings with you in the little office, planning to organize the nonorganized [...] I believe that this school is a start for those who know nothing, and training school for those who do know a little and need a thorough review of what they know [...] I hope you will not fall asleep while reading this uninterested letter. ${ }^{10}$

I cannot know whether the actual recipient of the letter fell asleep, but for me, its external reader, the letter was a loud knock on the door of my 'ivory tower'. Once I opened the tower's door, the vistas of women workers' cultural worlds and intellectual lives started unfolding beneath my eyes. I didn't know that I was standing at the threshold of a new field of inquiries when I started reading the letter on this hot July afternoon; I was simply following its fascinating plot gradually feeling that I needed to know more. Apart from being tired, what I also remember vividly is the trance situation I entered while reading the letter slowly, and even more so when I started copying it verbatim. Why did I do it? I could have asked for a photocopy, which eventually I got. But this mechanical reproduction would have ripped away all the visceral excitement I felt while reading and copying the letter. Farge has written about the importance of copying practices in the archive:

In the digital age this act of copying can seem quite foolish. [...] And it would indeed be foolish, stubborn, maybe even pridefully obsessive ... if this exact recopying of words did not feel somehow necessary, an exclusive and privileged way of entering into the world of the document, as both accomplice and outsider [...] This flow of words can sweep you off into unexpected directions, taking you to a place poised somewhere between the familiar and the exotic. ${ }^{11}$

What the act of copying does then, is to freeze some moments and slow down the passing of archival time. What it also does is that it functions as a time machine, throwing you into different times and other spaces, the heterotopias and heterotemporalities of archival research that I have repeatedly mapped and discussed in my genealogical projects. ${ }^{12}$ Surely you can't experience space/time travels with your camera in hand trying to photograph as many documents as you can-a trend I have seen in different archives throughout the world. Of course, you will need to do it sometimes, when time is short, funding money is running out and you have found the source you were looking for. Yet, you should be aware that 'the archival moment' has been lost and/or has to be recreated elsewhere, at your desk perhaps after 'the return', when you feel doubtful about what to do with the precious documents you have brought from the archive. What about this moment then and why is it important?

Reading a document line, by line, taking the time to leaf through it and/or go backward and forward, triggers the process of understanding and interpretation, which always starts while in the archive, as I have already suggested in the collaborative project of theorising archival research in the social sciences. ${ }^{13}$ The archive fashions an 
experience of 'trance reading' and asks the researcher to slow down and throw themselves in the world of the documents. For Farge this experience is like 'a dive, a submersion, perhaps even a drowning ... you feel immersed in something vast, oceanic' she has poetically written. ${ }^{14}$ It is only when you have submitted yourself to the forces of the archive that you feel liberated from the grip of hegemonic understandings and you start discerning silences, absences, shadowed figures and marginalized storylines, in short the subjugated knowledges that genealogy is after. Copying is catalytic here, since it fully engages the body in this process of seeing and understanding and literally imposes the slow rhythm of the archival time: 'reading the archive is one thing; finding a way to hold on to it is quite another', Farge has noted in weaving together reading and copying as archival technologies par excellence. ${ }^{15}$

It is in the middle of this slow process of reading, copying and in effect rewriting the archive that the researcher re-emerges as a reader with new ideas about the archival documents. And in this light, it is not only the researcher who is being gradually transformed, but also the documents: they both 'become other' through their entanglement within the space/time context of the archival phenomenon. Elsewhere in my work I have written at length about the theoretical underpinnings of this process of feeling the archive as a living organism drawing on neo-materialist philosophies. ${ }^{16}$ In doing so I have made connections between the setting up of a scientific experiment within the laboratory and the archival experiment of working within the boundaries of specific documents, fonds, characters and periods. What I have argued is that in the same way that scientific measures, findings and outcomes are the effects of how the experiment was designed and set up in the first place, the knowledges and published outcomes that derive from archival research are situated within the parameters and boundaries of their 'phenomenon' or experiment in Karen Barad's configuration. ${ }^{17}$

But when thinking outside the box and beyond the conditions and restrictions of 'the phenomenon', the metaphor of 'flying' has become a forceful mode of making connections between the materiality of archival research with the possibilities opened up by the archival imagination: 'the true method of discovery is like the flight of an aeroplane. It starts from the ground of particular observation; it makes a flight in the thin air of imaginative generalisation; and it again lands for renewed observation rented acute by rational interpretation' ${ }^{18}$ Alfred North Whitehead has written. The process of archival research can indeed be both thick and thin: thick when it starts digging or diving deep into archaeological sites of accumulated memories and knowledges and thin when it flies up in the blue skies of ideas and the fictions of imagination. What is important to note here is that thickness and thinness should not be taken as a binary, or a grammatical opposition, but rather as an assemblage of thick and thin components, making multifarious internal and external connections between, amongst and outside themselves. ${ }^{19}$ The metaphor of flying also addresses the question of how to oscillate between involvement in and detachment from the problem a genealogist is investigating in the archive, what Nietzsche has described as 'pathos for distance. ${ }^{20}$ While being immersed in the world of the archival documents, the genealogist needs to take a distance, so that they can discern and interrogate common sense understandings and normative discourses; they need to take an angle 
that will allow them to see differently. It is around this entanglement/distance tension that the metaphor of flying is revolving.

Given my situated position as a feminist genealogist I have always considered my archival work as an on-going series of excavations. Foucault's influence was clearly catalytic here: 'genealogy is the aim of the analysis and archaeology is the material and methodological framework', he said in one of his Berkeley lectures, ${ }^{21}$ further adding that 'I never stopped doing archaeology. I never stopped doing genealogy' 22 . The task of the archaeological method in Foucault's approach is to excavate accumulated layers of discursive formations so as to reveal discontinuities, contingencies and ruptures in what seems to be 'natural' or 'necessary' in the history of sciences, ideas, concepts and practices. It goes without saying that the idea of archaeology as a method fits perfectly in the practices of archival research, particularly when you think of all these documents stored in library and museum basements, waiting to be retrieved, reread and rewritten. When it comes to women's history this excavation into the thickness of hidden layers of documents and knowledges is the usual experience of the researcher, even today.

In flagging up the importance of recovering lost archives Joan Scott has written about how fragments of Marie-Louise Bouglé's library in France was unearthed from the basements of the Bibliotheque Historique de la Ville de Paris (BHVP), by Maïté Albistur, a graduate student then, who eventually catalogued it and made it available to researchers. ${ }^{23}$ I was amongst those researchers, who benefited from Albistur's invaluable archival work and it was there that I had the first signs of the importance of education in women workers' lives. However, since the papers of the initial collection had been scattered in boxes in the basement of the BHVP for some forty years, I had to struggle with misplaced and lost documents. Moreover, the scattering of the documents has been extended to the fragmentation of their citations, exacerbated by the fact that the on-coming rush of digitisation has not been yet incorporated in the full citations of these documents. Even the references in the existing literature were sometimes misleading, since catalogue systems and codes keep changing and it is very difficult for researchers to track them. There were for example 11 letters from Désirée Véret-Gay and Jeanne Deroin, two leading activists and educators of the first autonomous feminist movement in nineteenth century France, ${ }^{24}$ that were supposed to be in 'Cartons 42 and 47' in the Fonds Bouglé of the BHVP, according to historian's Michelle Riot-Sarcey list of sources..$^{25}$ The problem was that there is not even such a thing as Fonds Bougle in the official BHVP catalogue anymore. Bouglé's papers have now been renamed as Archives Marie-Louise Bouglé, since they include fonds of many feminists. Moreover, the whole system of 'cartons' has changed and when I visited the library in September 2014 looking for these 11 letters, the archivists were unable to find them. It took me 7 months, many e-mail exchanges with the archivists and a second visit to the BHVP in April 2015, to eventually locate them, after following an obscure footnote in a draft of a conference proceedings paper in the Bibliothèque Marguerite Durand. ${ }^{26}$

Foucault has argued that genealogy 'operates on a field of entangled and confused parchments, on documents that have been scratched over and recopied many time' ${ }^{27}$ 
My documents were not only scratched and recopied, but also misplaced and renamed. While immersed in 'the dust' of the archive that Carolyn Steedman has so influentially theorised, ${ }^{28}$ I was further deeply upset to find out that the protagonists of my research had no specially curated collections of their papers, in the archival tradition of the fonds. According to Jaques André, the preservation of fonds in the archives 'respects' the formation of documents around a person or an institution, however it was derived, 'and refrains from breaking it up'. ${ }^{29}$ It seems however that the feminist pioneers in France never became the subjects of fonds, or the objects of respect for that reason. Instead, they remained buried and scattered in dusty basements, or they were perhaps left floating in the depths of the ocean. Farge has actually made connections between the archival fonds and the basses, "hulking masses of rocks in the Atlantic [...] that are visible only twice a year, during the lowest tides $^{\prime 30}$, thus bringing maritime archaeology in the way she visualizes the archive in terms of archaeological imageries. The discovery of the Bouglé collection was one of those 'low-tide' moments when the basses became visible, soon to be covered by the high tides of changing cataloguing and citation practices again.

But to return to Whitehead's metaphor of flying, while archival research is deeply entangled in the thickness of archaeological excavations, it also includes the ethereal experience of the thinness of imagination: 'The world of imagining is a thin world, a mini-world whose ephemerality precludes any engaged activity comparable to that required in the life-world' ${ }^{31}$ Edward Casey has written in his phenomenological study of imagination. Casey's analysis has drawn on Spinoza's philosophy, wherein reason and imagination co-exist in the multifarious ways that understanding emerges and knowledge is constituted. As Genevieve Lloyd has pointed out in her excellent study of the Ethics: 'fictitious or "feigned" ideas are mixed methods of knowing. They partake of imagining, but through being criticised by reason they become a source of improved understanding.' ${ }^{32}$ Foucault has also pointed to the constitutive role of imagination in writing genealogical histories: 'one 'fictions' history on the basis of a political reality that makes it true, one 'fictions' a politics not yet in existence on the basis of a historical truth' ${ }^{33}$ Genealogical histories then problematise our present, first by detaching it from the debts of the past and secondly by opening up unimagined or unthought-of possibilities for the future.

Archival imagination has thus become a hot topic in the existing literature and has been discussed from a wide range of angles and theoretical perspectives. ${ }^{34}$ What has been mostly highlighted is that the archival imaginary is constitutive of the possibilities for knowledge-making'. ${ }^{35}$ So what exactly is happening when 'we are flying' while immersed in the nuts and bolts of archival research? The archive seizes moments in the life process that have been symbolically transformed into novellas and images or have left their traces upon artefacts, memorabilia or simply forgotten and/or lost objects. When we see, read or touch such traces of the past, we feel that we have somehow grasped 'the real', no matter how fleeting or ephemeral such experiences have been. And yet the idea of 'touching the real' is an illusion, Farge has pithily noted: 'No matter how much the real seems to be there, visible and tangible, it reveals nothing more than its physical presence, and it is naïve to believe that this is its essence'. ${ }^{36}$ The importance of the archival object, be it a story, an administrative document, a photograph or a piece of string that slips out of an envelope, 'lies in the 
interpretation of its presence, in the search for its complex meaning, in framing its "reality" within systems of symbols-systems for which history attempts to be the grammar', Farge argues. ${ }^{37}$ This is precisely where 'flying' works: it throws the researcher in the air, disentangles him or her from the material and affective forces of 'the natural presence' and creates the necessary distance for understanding and interpretation beyond the stubbornness of common sense notions and perceptions. Flying both metaphorically and literally enables the researcher to see things differently and ultimately creates conditions of possibility for critical analyses and radical knowledges. It is while in the air that intuitive understanding, as the highest level of knowledge emerges - an intellectual 'love for the world' in Spinoza's philosophical universe.

Spinoza's theory of knowledge has initiated a line of progressive pedagogical thinkers and has been particularly influential upon John Dewey's notion of 'creative imagination' that was central in the movement for workers' education: 'In its highest form imagination is not confined to isolation and combination of experiences already had [...] It is virtually creative. It makes its object new by setting it in a new light' Dewey wrote. ${ }^{38}$ Following his lead, Fannia Mary Cohn wrote that seen it the context of in workers' education 'creative imagination' opens up the dark side of things, reveals hidden meanings and helps workers to re-imagine themselves and their relation to the world. ${ }^{39}$ Cohn was a prominent figure in the international movement for workers' education and in constant correspondence and collaboration with Dewey, amongst other public intellectuals of her geographies and times. ${ }^{40}$ Yet, very few of her articles have ever been published, while the bulk of her historical, political, literary and personal writings can only be read in the archives. ${ }^{41}$ What is even more intriguing is that she personally collected and bequeathed her papers to the New York Public Library, where I traced and read them. It is to this captivating twist in the provenance of archival documents originated by women workers that I will now turn.

\section{Archival Technologies of the Self}

Questions around provenance are prevalent in the literatures theorising the archive. How a document or a collection of papers was assembled and later found their way and indeed place in the archive is of particular interest and has informed discussions around institutional authorities, colonial histories and gate keeping practices-in short the knowledge/power relations that are entangled in archival research. As we have suggested in our co-authored book, The Archive Project, the notion of 'the archivist function' can throw light into the deployment of such practices and relations. ${ }^{42}$ Drawing on Foucault's notion of 'the author function', we have pointed to 'the social, material and cultural conditions that underpin the institutional foundation and organisation of archives' ${ }^{43}$, raising questions about how collections of papers were created, deposited, classified, maintained and ultimately used. Provenance we have argued 'can often provide important information vital to analysis and interpretation'. ${ }^{44}$ In the same way that Foucault showed how through the lens of the 'author function' we could trace genealogies of the author-text relation, 'the archivist function' can unveil power/knowledge entanglements between collections, archives 
and archivists. It is therefore in the context of tracing genealogies of archival formations that I want to discuss how the knowledge that the collections and fonds I was working with, both in Paris and in New York were 'auto-archives'.

Given that archival collections and practices do not come out of the blue, my first move was to create a plane of consistency for women workers' auto-archival practices to be mapped and contextualized. As Scott has shown the creation of archives around women's history only started in the twentieth century and it is only recently that historians have been able to discern some patterns of how it developed on both sides of the Atlantic. ${ }^{45}$ Unsurprisingly it was feminist activists, who initiated such archival practices. As Scott notes, 'these women had a sense that they were making history and that the memory of their activity must be preserved for posterity'. ${ }^{46}$ Moreover, the creation of archives from, about and for women was connected to the movement for women's education: 'there is a connection between the pursuit of women's education and the documentation of women's past activities' 47 , Scott has commented. As I have shown in my work, workers' education was part of this movement, although not sufficiently explored by feminist historians. Consequently, the histories of their archives and personal collections have to be included in the histories of women's archives, including the feminist archives that are on the making. It is women's invisibility rather than absence that has been suggested as the main problem of their status in the historical records, including the recently created feminist ones. ${ }^{48}$

The creation of archives for women's history was therefore the effect of a developing culture of historical consciousness, which went hand in hand with the emerging phenomenon of 'archival sensibility' ${ }^{49}$. Through their involvement in the social movements of their geographies and times, women were increasingly aware that they were making history, but also that unless they found a way to record their actions, the memory of their struggles would be erased. By that time, they were educated enough to know that women were absent from major museums, libraries, archives and bibliographies and could see the urgency of preserving the memory of acts and deeds that were unfolding beneath their eyes. What a genealogical exploration of such archival practices reveals is that the development of a feminist historical consciousness was not a linear and unproblematic process: instead it carried the scars of race and class differences. Cohn's letter to historian Mary Beard at the time that the the World Center for Women's Archives was being established forcefully expresses her support for this project, but also her fears that working women might be neglected or de facto excluded from the feminist project of recording women's history:

I agree with you as to the importance of having a World Center where a record of women's achievements will be preserved. Of course, this should be done not only for the sake of encouraging women by making use of their experience and achievements, but also for general historical reasons. I do hope that in your efforts to get justice for women by recognising their achievements, your Board will not make the mistake of not including the records of certain social groups in your archives. I am sure, also, that your Board of Directors will have 
representatives of each group speak for themselves. If I may, as one who is interested in the growth of such a Center, I would like to suggest that there should be another class of membership fee. So many will be eager to assist in your efforts, who will find it difficult to contribute $\$ 5.00$ a year ... ${ }^{50}$

It is in this context that Cohn took the decision to collect her papers and bequeath them to the New York Public Library (NYPL), where they are still housed. During her long service in the educational department of the International Ladies Garment Workers' Union between 1918 till her death in 1962, Cohn was in constant collaboration with the NYPL librarians. Together they worked to organise 'the book division'-a union based library, which was one of Cohn's favourite projects, her 'baby', as she used to call it. ${ }^{51}$ It was thus only natural that she felt that the NYPL would be the ideal place to shelter her memories as a labour educator and union activist. We also know that collecting her papers was a life-long project and not a decision of the moment. In politely declining the invitation from a friend, who had asked her for some biographical details for a forthcoming publication, she had noted that 'I can back all this with many letters that I keep in a safe. Some day you will have access to them, but not now' ${ }^{52}$ Cohn was thus already, always in the process of archiving herself and she formally institutionalized her collection as her swan song to the labour movement. In collecting documents of her involvement in the history of the labour movement she was also creating an archive of her constitution as a political subject, indeed she actively formed herself as such. As Foucault has shown, genealogy conceives subjectivities and social relations as an effect of the interweaving of discourses and practices, which it sets out to trace and explore.

What were then the implications of such 'auto-archival' practices for my analysis? Collecting photographs, personal documents, including journals, diaries, letters, postcards, but also cinema and theatre tickets, exhibition catalogues, little souvenirs from places we have visited, or just a yellow leaf that fell on the street on the first days of autumn, are archival practices that we are constantly entangled in, day after day. In this sense 'the archive' should not necessarily be linked to state institutions, such as museums and libraries: 'it can variously also be a building, cardboard box, photograph album, internet website or discourse of interconnected ideas such as community heritage and shared memory'. ${ }^{53}$ The archive and its contents can thus take different forms that range from button boxes to gothic vaults and can include paper documents, audio files, photographs and moving images, as well as material objects, to name but the most usual. In this sense, we keep creating archives as we go on living-archives are entangled in the materiality of our daily, mundane memories.

It is on this plane of 'material archives in becoming' that I have initially mapped women workers' auto-archival practices. It goes without saying however, that not all of their collections, be they texts, images or objects, found their way in the archive. There were obviously archival 'items' that were lost, destroyed, misplaced or forgotten-serendipity is always part and parcel of how collections are being formed-but most importantly there were careful selections and deselections. These are issues that have been widely discussed in the rich bodies of literature that revolve 
around the epistemological constraints of auto/biographical research in general and women's self-documents in particular. ${ }^{54}$ What has been identified as an important theme in this rich body of literature is that autobiography should not only be conceptualised as a mode of writing, but also and perhaps more importantly as a mode of reading. ${ }^{55}$ If we are to transfer this insight to 'auto-archival' practices, the interest should not only be on how these practices were deployed, but also to how we can read and understand them as 'regimes of truth'. As Farge has pithily commented, 'the archives do not necessarily tell the truth, but as Michel Foucault would say, they tell of the truth'. ${ }^{56}$

In this light auto-archival practices expose how women labour activists like Cohn responded to the constraints they were subjected to within the patriarchal regimes of power and more specifically how they found ways to etch the memory of their appearance in the politics of their geographies and times. Understanding is important here within the overall Spinozistic spirit of my inquiries: 'I have laboured carefully, not to mock, lament or execrate, but to understand human actions', Spinoza famously wrote in his Political Treatise. ${ }^{57}$ In my attempt to understand women's actions then, I followed patterns of presences and absences in the documents they saved, the classifications they created and the groups of people they flagged up as 'significant others' in their life and work. Following such practices of archiving the self, Cohn's case was particularly intriguing, since she did not leave any diary, journal or memoir in her papers. By following the discursive order of her archive however, I could discern a design that had a meaning and could ultimately sketch what I have configured as her 'archival portrait'. Seen in the light of my genealogical inquiries, Cohn's papers have created an archive of 'counter-memories', leading to a transformation of labour history in the way Foucault has influentially theorised the concept. ${ }^{58}$ Such transformations were the effect not only of dusty, scratched and forgotten texts, but also of visual images, as I will discuss next.

\section{In pictures}

While working with women workers' personal and public documents, I was drawn to their collections of photographs, particularly intrigued by their decision to include them in the papers they bequeathed to the archives. The themes, figures and ambience of the photographs have added multiple layers of complexity in the way women workers' life and work can be read and understood and I have discussed them elsewhere in my work, situating my analysis in a growing body of literature around the use of photographs in life history research. ${ }^{59}$ What emerges from this burgeoning body of literature is that despite the fact that 'the truth' of/in photography has been interrogated from a wide range of theoretical positions and perspectives, there is still a hovering idea that a shadow or an inscription of 'the real' can somehow be traced in a photographic image, whether it comes from a professional photographer, an amateur or an artist.

The idea of taking and collecting photographs is also very much related to everyday mnemonic practices, the desire to preserve something of the fleeting present. In this 
context people take and collect photographs on various occasions and for various reasons, while institutions have always created, kept and archived photographs in the process of documenting the history of their activities and establishing their legacy. Scholars in the history of education have been increasingly drawn to photographic archives and other visual sources in their analysis, pointing to the ways that the visual exposes complex interrelations between educational spaces, bodies, subjectivities and institutions. ${ }^{60}$ There was thus an interesting mixture of personal and institutional group photographs in the women workers' collections I worked with. What is the ontological and epistemological function of these photographs and how are women workers' practices of collecting and archiving photographs to be understood? These are genealogical questions par excellence, that I will discuss in this section, following Penny Tinkler's suggestion that we should look more closely at the 'life of a photo', raising questions about the conditions of its production, its intended audiences, the ways it was kept and stored, as well as its reception. ${ }^{61}$

Photography can be taken as a skiagraphy, Jaques Derrida has suggested, it is about the writing of light, as well as the writing of shade, an apparatus where regimes of visibility and invisibility are intertwined. ${ }^{62}$ There are strong connections here between Derrida's skiagraphy and the genealogical analysis that has been described as a grid of distributing the visible and the invisible. As I have discussed elsewhere in my work, women's involvement in education has created regimes of exemplary visibility, as well as regimes of shadow and darkness, further suggesting that the genealogical analysis can be taken as 'an impressionist painting, blurring lines, colours and shadows'. ${ }^{63}$ But apart from offering images of light and shadow, diffractions and interferences, photographs also constitute 'a reply' to the living world, 'a witness without witness, the prosthetic eye, an eye too many but invisible, at once producer and preserver, the origin and the archive'. ${ }^{64}$ Moreover, photographs elicit affects: 'we come to suspect that desire, even love itself, is always born of a certain photographic sketch', Derrida has pointed out. ${ }^{65}$ Photography therefore revolves around the desire for truth taken as aletheia in its ancient Greek etymology: revealing, exposing, throwing light to something that it is concealed, forgotten or distorted. What is important to remember here is that Derrida's approach to the truth in photography follows Heidegger's lead in making a distinction between truth as 'unhiddenness' and truth as correspondence:

Initially, the meaning of the Greek word for truth, unhiddenness, has nothing to do with assertion and that factual contexture in terms of which the essence of truth is usually explained, i.e. correctness and correspondence. To be hidden and unhidden means something quite different to correspondence, measuring up, directedness towards ... Truth as unhiddenness and truth as correctness are quite different things; they arise from quite different fundamental experiences and cannot at all be equated. ${ }^{66}$

In this light although we can see photographs as responses to the world, as well as assemblages of lights and shadows, what they unhide, expose or reveal should not be linked to mirroring or representing an image of the real. Photographs should be taken as 'sites of enunciation' Manoela dos Anjos Afonso has argued, exploring the role of 
photographs and their connection to language and places. ${ }^{67}$ Such places of enunciation however are located 'neither in the photograph, not in the photographed element' ${ }^{\prime 68}$; they rather emerge in relation to other photographs that form a visual assemblage, be it a family album, a photo-diary, an institutional yearbook or a file bequeathed to an archive. It is in this context that 'the digital revolution', which is unfolding beneath our eyes, opens up vistas for contextualizing individual photographs and will further enable the mapping and analysis of visual assemblages. Either taken as a site of enunciation or as 'a locus of meaning', according to Andrew Benjamin, ${ }^{69}$ a photograph is always already the effect of certain practices, including 'technologies of production and interpretation' ${ }^{70}$, but also technologies of collecting and archiving I would add. It is while considering technologies of producing, interpreting and archiving that we can better grasp how photographs problematize relations between memory, history and the personal, as Benjamin has pithily observed. ${ }^{71}$ So, while photographs can never mirror or represent 'the real', they speak of it, they are 'of the real' and they open up loci of enunciation for the self. Moreover, while they freeze 'moments of being' or 'moments of action', they also necessarily exclude what Benjamin has identified as 'the next moment':

A leaf moves, a smile occurs, hands touch and strangers pass each other on the street. In the next moment, the leaf is at rest, the smile has become a laugh, hands part, and a different set of strangers pass each other. In all of these instances activity is equated with a moment. The photographic image presents that moment. What it cannot present is of course the next moment. ${ }^{72}$

What I therefore argue is that it is in the lacuna of 'the next moment' that women workers' practices of archiving photographs have to be situated, in order to be understood. The 'next moment' is always, already absent, but the photograph becomes a sign of its radical futurity, the open possibilities that it carries with it: an immigrant dressmaker talks on a platform, a group of seamstresses picket in a line, a class of textile workers laugh their hearts out during a lecture, a party of labour organisers take a walk in-between the business of their annual convention, three women read under a tree in the Bryn Mawr campus... These are all moments captured in the photographic images that I was drawn to in my analyses. ${ }^{73}$ They all point to open and unimagined futures that the movement for workers' education was envisaging. Photographs carry traces of the 'moment of action', but also of 'the next moment' and this is why they were carefully collected and bequeathed to the archives: as documents of actual events, as well as signs of virtual possibilities. As already pointed out above, the digital revolution has widened the horizon of 'the next moment'; photographic inscriptions captured in the archive can now be seen in the context of wider collections that can open up through a simple 'click' in the digital photographic archives that are increasingly emerging. The digital turn, as I have discussed it elsewhere at length, ${ }^{74}$ carries of course new questions and problems around the ontological and epistemological status of the transposed archival documents, and invites new methodological approaches that can address the specificities of their study and analysis. ${ }^{75}$ 
But beyond their function as inscriptions of moments, these photographs also act as 'primal phenomena' in the understanding of the past, 'opening up a vision of something to which one would otherwise never have had access'. ${ }^{76}$ In coining the notion of photographs as 'primal phenomena' Elaine Miller draws on Walter Benjamin's project of 'primal history':

Illuminating unrecognised moments of the past in a movement that Benjamin describes as 'flashlike', the articulation of primal history both preserves the past from oblivion and illuminates the possible future as the unredeemed or repressed consequence of those forgotten moments. To understand primal history, one must glean a conception from multiple fragmentary sources. ${ }^{77}$

Taken as a fragmentary source of primal history, the photograph as a flash of the past enters in dialogue with the present 'to form a constellation' Benjamin has written in The Arcades Project. ${ }^{78}$ Let us then think of the institutional and documentary photographs of the labour movement as flashes of the past into the present. As we look at them in the archive, it is not only frozen moments of time that we reflect upon, but also virtual possibilities of what might have been in the linearity of the historical time that we can imagine. Photographs bequeathed to archives also give us the opportunity to view the past in the same way that the women activists, who collected them, did. We look at the moments they cherished and considered as 'worth keeping' and we start wondering why. It goes without saying that we will never follow the same tracks of meaning making. However, these photographic images emit signs that might disrupt our usual pathways of understanding or draw our attention to visual details that would have gone unnoticed in the transcripts of lived experiences.

In discussing the photographs that I found in Cohn's papers, I drew on Barthe's notion of the 'punctum' 79 , as a force that 'wounds the eye' and draws the spectator's attention to something that lies beyond the frame and indeed the subject of the photograph: women activists' radical solitude in the ranks of the labour movement in the case of the photographs that Cohn collected. ${ }^{80}$ But I was also drawn to the floral patterns of the dress of a seated portrait of Cohn's at a desk in a garden, inscribing a different meaning in who she was and juxtaposing it to her depiction as a sad existence, suffering continuous mental health breakdowns. ${ }^{81}$ Cohn's floral dress as depicted in her photographic portrait has created new configurations in understanding her subjectivity. In Julia Kristeva's analysis, it has also acted as 'an imprint, or indication' 82 rather than a representation of who Cohn was. It is in putting together insights from Barthes' conceptualisation of the punctum, Benjamin's notion of primal history as an assemblage of flashes, as well as Kristeva's take of art as inscription, that Miller comes up with the notion of photographs as primal phenomena:

When the camera 'clicks', it severs a moment from the flow of linear time and isolates it in space, resulting in a presented moment that can be returned to immediately, after a long-deferred stretch of time, or never. The isolation of a moment or moments can have the effect of estranging us from our ordinary sequence of experiencing, considering or recalling events, resulting in an insight 
into them that was previously unavailable or inaccessible, a photograph as primal phenomenon. ${ }^{83}$

As on-line photographic archives are increasingly digitised and become available to wider audiences around the globe, 'the visual turn' in archival research will open up new areas of investigation, will raise new questions and present new challenges. Film studies will also be increasingly included in such approaches as documentary films and personal and institutional videos will be added to the welt of visual sources. I was in the final stages of submitting the manuscript on women workers' education, when a rare documentary film about the Bryn Mawr Summer School for women workers in the industry became available on you-tube. ${ }^{84}$ Although I knew about this film, as it was included in the bodies of literature I had reviewed for women workers' education, watching it was an invaluable experience in getting a more vivid and lively sense of what this school meant for the women workers who were lucky enough to have got a funded position to attend it. Given that the analysis of the archival documents had brought up the Spinozist theme of 'an ethics of joy' as a creative force in women workers' education, the moving images visualized this force and powerfully displayed the effects of corporeal expressions and encounters. As Charlotte Bates has persuasively argued visual methods are more sensorially attentive and in this sense they can better capture visceral bodies and register intense emotions and feelings. ${ }^{85}$ The film's open access also meant that the readers of my analysis could have direct access to the viscerality of the emotions and affects I was pointing to, as well as the opportunity of different readings and interpretations. The visual has thus brought light, sound and movement in what was previously supposed to be the silent world of the archive and it is here to stay.

\section{The force of archival research: housing 'the other'}

In looking back at my work in the archives of women workers' education I have configured the archive as a living organism in the process of becoming, a field of forces where events erupt, tracks are mapped, traces are unveiled and new knowledges emerge and crystallize. Such an affirmative image of what the archive is/becoming might seem to ignore or downplay regimes of power and regulation that are also entangled in the ways archives have been theorised either under the shadow of the Derridean arkhe, the actualization of the law, or in the critique of the imperial archive. As we have argued in The Archive Project, Foucault is also included in the theoretical underpinnings of the colonial archive through his critique of the power/knowledge relations of the institutions and his wider take of the archive as the library of libraries'. ${ }^{86}$ But as I have already pointed out, Foucault's archival work has been ignored in such deconstructive approaches to archival research and the question of why he spent most of his research life in archives has not been posed, let alone followed. But it is precisely Foucault's genealogical investigations at the heart of powerful institutional archives that have created epistemological conditions of possibility for their fierce critique. Simply put: you cannot effectively criticize 'the archive' without seriously engaging in archival research. Moreover, as long as 'the archive' is kept abstract and vague, it increasingly becomes stronger, more opaque 
and more wrapped up in myths and fantasies. Undoing the archive presupposes a raw and visceral engagement with its spatiality, rhythms and material liveness. This is why feeling the archive becomes a condition sine qua non of critical and effective histories in the way Foucault theorized them though the lenses of genealogy.

Throughout this contribution, I have shown how my genealogical inquiries in the history of women workers' education have shaped the ways I have worked in powerful institutional archives that have however welcomed marginalized and radical collections of papers. It was perhaps because they were so powerful that they could accept to house 'other documents', the migrant woman activist's traces in the case of my research. After many years of working in different archives around the world and later using their documents in writing and publishing, I have come to the conclusion that it is usually the imperial archives that are more relaxed and generous with allowing access and grating permissions for the use of their documents in academic writing and publishing. At the same time it is well known that 'radical archives' often impose strict regulations, restrictive boundaries and tiring bureaucratic mechanisms. These 'other documents' however cannot speak of themselves and by themselves. No matter how archival collections have come to be constituted, organized and housed, it is what we do with them that is equally important, particularly as we are excavating marginalised histories in women's education and beyond. The question therefore that is worth exploring in the writing of history of women's education [and beyond] is not 'what an archive is', but 'what an archive does'.

\footnotetext{
${ }^{1}$ Michel Foucault (1994) Lives of Infamous Men, R. Hurley (Trans.) in J. D. Faubion (Ed.) Michel Foucault: Power, The Essential Works 3, (New York: The New Press), pp.15775, at p. 158.

${ }^{2}$ Arlette Farge (1989). Le goût de l'archive. Paris: Gallimard. Translated as The Allure of the Archives (2013) by T.Scott-Railton (New Haven: Yale University Press). For Foucault's collaboration with Farge, see Farge and Foucault (1982) Le désordre des familles: lettres de cachet: Des Archives de la Bastille, (Paris: Gallimard).

${ }^{3}$ Maria Tamboukou (2017) Women Workers' Education: Life Narratives and Politocs: Geographies, Histories, Pedagogies, (Basingstoke: Palgrave Macmillan).

${ }^{4}$ See Tamboukou (2003) Women, Education and the self, a Foucauldian perspective, (Basingstoke: Palgrave Macmillan); Tamboukou (2010) In the fold between power and desire: Women artists' narratives, (Newcastle-upon-Tyne: Cambridge Scholars Publishing); Tamboukou (2016) Gendering the memory of work: women workers' narratives, (London: Routledge).

${ }^{5}$ Michel Foucault (1986) Nietzsche, Genealogy, History in The Foucault Reader, P. Rabinow (Ed.), (Harmondsworth: Peregrine), pp.76-100.

${ }^{6}$ Foucault (1979) Discipline and Punish, A. Sheridan (Trans), (London: Penguin), p.31.

7 Elsewhere in my work, I have discussed at length the notion of 'the event', particularly focussing on Foucauldian and Deleuzian approaches. See Tamboukou, Nomadic Narratives, Visual Forces: Gwen John's Letters and Paintings (New York: Peter Lang), particularly Chapter 1.
} 
${ }^{8}$ Moore Niamh, Salter Andrea, Stanley Liz and Tamboukou Maria (2016) The Archive Project: Archival Research in the Social Sciences, (London: Routledge).

${ }^{9}$ Ibid., 177

${ }^{10}$ Letter from Rose Pesotta, dated August 4, 1922, General Correspondence, Box 1, 1922-1928. Rose Pesotta papers. Manuscripts and Archives Division. The New York Public Library. Astor, Lenox, and Tilden Foundations (RPP/NYPL/GC/B1/1922-28). For an extended discussion of this letter, see Tamboukou (2013) Educating the seamstress: studying and writing the memory of work, History of Education 42(4), pp.509-527.

${ }^{11}$ Farge, The Allure, p.16.

12 See Tamboukou, Women, Education and the Self, Nomadic Narratives and Gendering the memory of work.

${ }^{13}$ See Niamh et al., The Archive Project.

${ }^{14}$ Farge, The Allure, p.4.

15 Ibid., p.15.

${ }^{16}$ See Tamboukou (2016), Feeling narrative in the archive: the question of serendipity, Qualitative Research 16(2), pp.151-166.

17 See, Tamboukou (2014), Archival Research: unravelling space/time/matter entanglements and fragments, Qualitative Research 14(5), pp.617-633.

${ }^{18}$ Alfred North Whitehead (1985) [1929] Process and Reality [Corrected Edition]. (New York: The Free Press), p.5.

${ }^{19}$ I am thankful to Liz Stanley who, has commented on the risk of this binarism in a symposium on archival research in March 2017.

${ }^{20}$ See Rosalyn Diprose (1993) Nietzsche and the pathos for distance, in P. Patton (Ed.) Nietzsche, Feminism and Political Theory, (London: Routledge), 1-26, at p.6.

${ }^{21}$ Foucault (1983) 'The Culture of the Self', lecture at Berkeley. Michel Foucault, Audio Archive, Library, University of California, Berkeley, http://www.openculture.com/2014/08/michel-foucaults-lecture-the-culture-of-theself.html [Accessed, 27-2-2017]

22 lbid.

${ }^{23}$ Joan Wallace Scott (1987) New Documents on the Lives of French Women: The Journal of Caroline B., 1864-1868. Signs: Journal of Women in Culture and Society, 12 (3), pp. 568-572, at p.569.

24 I have discussed the French seamstresses lives and deed in Tamboukou (2015), Sewing, Fighting and Writing: radical practices in work, politics and culture, (London: Rowman and Littlefield).

${ }^{25}$ Michèle Riot-Sarcey (1994) La démocratie à l'épreuve des femmes: Trois figures critiques du pouvoir 1830-1848. (Paris: Editions Albin Michel), p.346.

${ }^{26}$ Vaughan B. Baker (1997) Jeanne Deroin : The Years in Exile'. In Proceedings of the Western Association of French History. Saskatoon, Saskatchewan, October 15-18, 1997, 1-16. [Archived paper, Bibliothèque Marguerite Durand, Broc. MF 1674], at p.15, n.20.

${ }^{27}$ Foucault (1986) Nietzsche, Genealogy, History, p.76.

${ }^{28}$ Carolyn Steedman (2001) Dust, (Manchester: Manchester University Press).

${ }^{29}$ Jacques André (1986) De la preuve à I'histoire, les archives en France, Traverses 36, pp. 22-33, at p.29.

${ }^{30}$ Farge, The Allure, p.4. 
${ }^{31}$ Edward Casey (1976) Imagining: A Phenomenological Study (Bloomington: Indiana University Press), p.190.

${ }^{32}$ Genevieve Lloyd (1996) Spinoza and the Ethics (London: Routledge), p.61.

33 Foucault, The History of Sexuality, an interview in C. Gordon (Ed.) Power/Knowledge: Selected Interviews and other writings 1972-1977, (London: Harvester Wheatsheaf), pp. 183-193, at p. 193.

${ }^{34}$ For an illuminated discussion of imagination in archival research, see Niamh Moore (2016) Weaving archival imaginaries: Researching community archives in Moore et al., The Archive Project, pp. 129-152.

35 Ibid., p.150.

${ }^{36}$ Farge, The Allure, p.11.

37 Ibid., 12.

38 John Dewey (1887) Psychology (New York: Harper and Brothers), p.196.

39 'Workers' education today and tomorrow', unpublished essay, Writings, FCP/NYPL.

${ }^{40}$ For an extended discussion of Cohn's involvement in the intellectual circles of the early $20^{\text {th }}$ century, see Tamboukou, Women Workers' Education.

${ }^{41}$ Fannia M. Cohn papers. Manuscripts and Archives Division. The New York Public Library. Astor, Lenox, and Tilden Foundations. (NYPL/FCP/MSS588), http://archives.nypl.org/mss/588\#overview [Accessed 4 March 2017].

${ }^{42}$ Niamh et al., The Archive Project, p.160.

43 lbid.

44 Ibid., 165.

${ }^{45}$ Scott (1986) Women's Archives and Women's History, comments on the dedication of the Christine Dunlap, Farnham Archives, Brown University, October 10, 1986, at p.1. Available on line at: https://www.brown.edu/research/pembrokecenter/sites/brown.edu.research.pembroke-

center/files/uploads/JWSExcerpt 06957 0.pdf [Accessed 3-3-2017]

${ }^{46} \mathrm{lbid}$.

47 lbid.

${ }^{48}$ Scott, New Documents, p.568.

${ }^{49}$ See Moore et al., The Archive Project, pp.168-9 for an extended discussion of 'archival sensibility'.

${ }^{50}$ Fannia Cohn to Mary Beard, letter dated 23 January, 1940 (NYPL/FCP/Cor).

${ }^{51}$ Fannia Cohn to Morris Bialis ILGWU Vice President, letter dated 26 August, 1958 (NYPL/FCP/Cor).

${ }^{52}$ Fannia Cohn to 'dear friend', letter dated 28 July, 1937 (NYPL/FCP/Cor).

${ }^{53}$ Moore et al., The Archive Project, p.1.

${ }^{54}$ See amongst others, Liz Stanley (1992) The Auto/Biographical I: Theory and Practice of Feminist Auto/Biography (Manchester: Manchester University Press) and Sidonie Smith and Julia Watson (1998) (Eds.) Women, Autobiography, Theory: A Reader (Madison: University of Wisconsin Press).

55 Philippe Lejeune has been influential here. See Philippe Lejeune, Philippe (1989 /1973). The Autobiographical Pact, in P. John Eakin (Ed.), On Autobiography, (Minneapolis: University of Minnesota Press), pp.3-30.

${ }^{56}$ Farge, The Allure, p.29. 
57 Benedict de Spinoza, A Political Treatise [PT I 4], in A Theologico-Political Reeatise and A Political Treatise, R.H.M Elwes (trans) (New York: Dover Publications), pp.287387 , at p.288

${ }^{58}$ Foucault, Nietzsche, Genealogy, History', p.93.

${ }^{59}$ See Tamboukou, Women Workers' Education. For an overview of the literature around photography and life writing, see amongst others Linda, Rugg, Haverty (1997) Picturing Ourselves: Photography and Autobiography (Chicago: Chicago University Press); Timothy D. Adams, (2000) Light writing and life writing: photography in autobiography (Chapel Hill and London: The University of North Carolina Press); Nathalie Edwards, Amy L. Hubbell, Ann Miller (2011), eds. Textual and Visual Selves: Photography, Film and Comic Art in French Autobiography. (Lincoln and London: University of Nebraska Press and Brophy Sarah and Hladkl, Janice (2014) (Eds.) Embodied Politics in Visual Autobiography (Toronto: University of Toronto Press).

${ }^{60}$ See amongst others, Catherine Burke (2001) Hands on History: Towards a Critique of the 'Everyday', History of Education 30 (2), pp. 191-201, Ian Grosvenor and Martin Lawn (2001) Ways of Seeing in Education and Schooling: Emerging Historiographies, History of Education 30, pp.105-106 and Alexandra Allan and Penny Tinkler (2015) 'Seeing' into the past and 'looking' forward to the future: visual methods and gender and education research. Gender and Education, 27(7), pp. 791-811.

61 Penny Tinkler (2013), Using Photographs in Social and Historical Research (London: Sage), p.15.

62 Jacques Derrida (2010/1993) 'Aletheia', P. DeArmitt and K. Saghafi (trans), The Oxford Literary Review 32(2), pp. 169-188.

63 See Tamboukou (2003) Genealogy/Ethnography: Finding the Rhythm, in M. Tamboukou and S. J. Ball (Eds.) Dangerous Encounters: Genealogy and Ethnography, (New York: Peter Lang), pp.195-216.

${ }^{64}$ Derrida, Aletheia, p. 172.

65 Ibid., 175.

${ }^{66}$ Martin Heidegger (2002) The essence of truth: On Plato's parable of the cave allegory and Theatetus, T. Sadler (trans), (London: Continuum), p.8

${ }^{67}$ Manoela dos Anjos Afonso (2017) Language and Place in the life of Brazilian women in London: writing life narratives through art practice. Unpublished PhD thesis, University of the Arts, UK.

68 Ibid., p. 141.

${ }^{69}$ Andrew Benjamin (2010) 'What, in truth, is Photography? Notes after Kracauer, The Oxford Literary Review 32(2), pp. 189-202, at p.190.

70 lbid.

71 Ibid., 191.

72 Ibid., 197.

${ }^{73}$ See Tamboukou, Women Workers' Education.

74 See Tamboukou (2017) The visual turn and the digital revolution, $a / b$ : Auto/biography studies, 32(2), pp.359-362.

${ }^{75}$ For a discussion of issues arising from such digital archives, see amongst others, Tanya Dalziell and Paul Genoni (2014) 'Google comes to Life: Researching Digital Photographic Archives', Convergence: The International Journal of Research Into New Media Technologies, 21 (1), pp. 46-56. 
76 Elaine Miller (2010) 'Primal Phenomena and Photography', The Oxford Literary Review 32(2), pp. 203-230, at p.221.

77 lbid., p. 210.

78 Walter Benjamin, (1999) The Arcades Project, H. Eiland and K. McLaughlin (trans), (Cambridge MA: Harvard University Press), p.463; N3, 1.

${ }^{79}$ Roland Barthes (2000) [1980] Camera Lucida, R. Howard (trans), (London: Vintage).

${ }^{80}$ See Tamboukou, Women Workers' education.

81 Ibid., 171.

${ }^{82}$ Miller, Primal Phenomena, p.224.

83 Ibid., 226.

${ }^{84}$ Rita, R. Heller (1985) The Women of Summer, a documentary film, directed by Susan Baumer, produced by Rita Heller. Available on-line at:

https://www.youtube.com/watch?v=9hOiOreS8zQ [Part I]

https://www.youtube.com/watch?v=HoRSemT8jCg [Part II] [Accessed, March 3, 2016]

${ }^{85}$ Charlotte Bates (2013) Video Diaries: Audio-Visual Research Methods and the Elusive Body, Visual Studies 28(1), pp.29-37.

${ }^{86}$ Moore et al., The Archive Project, p.10. 